Article

\title{
Integrated Treatment at Laboratory Scale of a Mature Landfill Leachate via Active Filtration and Anaerobic Digestion: Preliminary Results
}

\author{
Filippo Fazzino, Stefania Bilardi (D), Nicola Moraci *(D) and Paolo S. Calabrò *(D) \\ Department DICEAM, Via Graziella, Mediterranea University of Reggio Calabria, Loc. Feo di Vito, \\ I-89122 Reggio Calabria, Italy; filippo.fazzino@unirc.it (F.F.); stefania.bilardi@unirc.it (S.B.) \\ * Correspondence: nicola.moraci@unirc.it (N.M.); paolo.calabro@unirc.it (P.S.C.)
}

Citation: Fazzino, F.; Bilardi, S.; Moraci, N.; Calabrò, P.S. Integrated Treatment at Laboratory Scale of a Mature Landfill Leachate via Active Filtration and Anaerobic Digestion: Preliminary Results. Water 2021, 13, 2845. https://doi.org/10.3390/ w13202845

Academic Editor: Antonio Panico

Received: 23 September 2021

Accepted: 9 October 2021

Published: 13 October 2021

Publisher's Note: MDPI stays neutral with regard to jurisdictional claims in published maps and institutional affiliations.

Copyright: (c) 2021 by the authors. Licensee MDPI, Basel, Switzerland. This article is an open access article distributed under the terms and conditions of the Creative Commons Attribution (CC BY) license (https:/ / creativecommons.org/licenses/by/ $4.0 /)$.

\begin{abstract}
The management of mature landfill leachate (MLL) represents an increasingly crucial issue to tackle. In this study, the feasibility of an integrated treatment was investigated at the laboratory scale using synthetic leachate with the objective of maximizing the recovery of potentially useful compounds present in leachate (especially ammonia nitrogen). First, in order to remove heavy metals, active filtration of the MLL was carried out using zero-valent iron (ZVI) mixed with either lapillus or granular activated carbon (GAC). The average removal rates for the ZVI/lapillus and the ZVI/GAC filter were 33\%, 85\%, 66\%, and 58\% and 56\%, 91\%, 67\%, and $75 \%$ for COD, Cu, $\mathrm{Ni}$, and $\mathrm{Zn}$, respectively. Then, pre-treated MLL was added during the anaerobic digestion (AD) of cellulose with the aim of providing bacteria with macro (i.e., ammonia nitrogen) and micro (e.g., residual heavy metals) nutrients. After 38 days, the best performance in terms of cumulative methane production $(5.3 \mathrm{NL})$ and methane yield $\left(0.26 \mathrm{NL} / \mathrm{gVS}_{\text {added }}\right.$ on average) was recorded in the reactor fed with the lowest dosage $(17.9 \mathrm{~mL} / \mathrm{d})$ of MLL pre-treated by the ZVI/lapillus filter. The main issue that emerged during $\mathrm{AD}$ was the possible inhibition of the process linked to an excessive presence of humic substances; however, in future experiments, this problem can be solved through an optimization of the management of the whole process. The residual digestate from $A D$, rich in nitrogen and humic substances, may be safely used for agriculture purposes, closing the cycle of MLL management.
\end{abstract}

Keywords: anaerobic digestion; granular activated carbon; lapillus; mature landfill leachate; recovery; zero valent iron

\section{Highlights}

- $\quad$ The sustainable management of landfill leachate (LL) is particularly problematic.

- Mature LL contains $\mathrm{NH}_{3}-\mathrm{N}$ and humic substances (HSs) that are potentially valuable.

- $\quad$ Mature LL also contains toxic substances such as heavy metals (HMs).

- $\quad$ Filtration on ZVI/GAC and ZVI/lapillus mixtures has been tested for removing HM.

- $\quad$ Pre-treated LL is used for integration of $\mathrm{NH}_{3}-\mathrm{N}$ in anaerobic digestion of cellulose.

\section{Introduction}

Among the potential environmental impacts arising from landfilling of waste, leachate generation constitutes a critical issue and its management is a major challenge [1]. Leachate quality is largely affected by landfill age and specific composition of waste disposed of [2]. On account of landfill age, leachate can be defined as young ( $<5$ years), medium age (5-10 years), and mature ( $>10$ years) [3] according to the anaerobic waste degradation processes occurring over the landfill lifespan [4]. Leachate characteristics change over time and are usually represented by basic parameters such as $\mathrm{pH}$, biochemical oxygen demand (BOD), chemical oxygen demand (COD), their ratio (BOD/COD), and ammonia nitrogen and heavy metal (HM) contents [3]. In particular, mature landfill leachates (MLLs) 
are collected from landfills when methanogenic microorganisms develop in waste and convert the readily biodegradable matter into biogas [4]. Thus, the organic fraction in MLL is dominated by refractory compounds such as humic and fulvic acids [3], as evidenced by the $\mathrm{BOD} / \mathrm{COD}$ ratio that is often in the range of 0.05-0.2 [2]. Ammonia nitrogen is the product of protein decomposition, and its concentration remains in the range of 500-2000 mg/L because no significant transformation mechanism occurs under methanogenic conditions in the landfill $[5,6]$. Metals can be present in leachate as colloids, organic and inorganic complexes, and free ions. Depending on $\mathrm{pH}$ values, HM concentrations are lower in MLLs than in young landfill leachates because most metals are less soluble at neutral $\mathrm{pH}$ values [2].

As required by several international regulations $[7,8]$ leachate must be managed for decades after landfill closure. Because, in many countries, there are thousands of landfills that are already closed or will be closed soon [9], a growing necessity of treating MLLs in the near future is expected. Currently, MLLs are treated by physical-chemical processes such as coagulation/flocculation, adsorption onto reactive granular filters, and advanced oxidation processes (AOPs) [10-14].

In this study, a novel approach was explored with the purpose of maximizing the recovery of the potential useful compounds present in MLLs. The process is divided in two phases: a pre-treatment using an active granular filter and anaerobic co-digestion of the pre-treated leachate.

Active granular filters constituted by granular activated carbon (GAC) and zero-valent iron (ZVI) have recently been used as a pre-treatment for young acid leachates prior to their ultimate treatment in biological processes [15-17]. GAC adsorption of organic and inorganic leachate pollutants is also quite common $[18,19]$.

Biological treatments are usually considered unsuitable for MLLs because of their low biodegradability and high concentration of refractory compounds [3]. However, the application of anaerobic digestion (AD) has great potential for integration into the treatment pathway of MLLs because macro (i.e., ammonia nitrogen) and micro (e.g., trace metals) nutrients are necessary for the optimal function of anaerobic microorganisms. In fact, several authors have suggested providing anaerobic digesters with opportune integrative solutions $[20,21]$ if substrates are inadequate in this respect. In this context, the current research aims at proving that pre-treated MLL can be used as a nutrient solution in AD, supplying trace heavy metals and nitrogen. The former are known to be stimulatory for anaerobic bacteria up to certain concentrations [22-24]. For instance, $\mathrm{Cu}, \mathrm{Ni}$, and $\mathrm{Zn}$ exert promoting effects on methanogenic activity if present in concentrations up to 100,50, and $5 \mathrm{mg} / \mathrm{L}$, respectively [25]. The latter is required for biomass synthesis [26] and can be helpful to reach the optimal carbon-to-nitrogen ratio $(\mathrm{C} / \mathrm{N})$ of 16:1-25:1 [27] in the case of $\mathrm{AD}$ of carbon-rich feedstocks (e.g., lignocellulosic materials). Conversely, humic substances (HSs) present in MLLs represent a hindrance because they have been shown to be inhibitory for hydrolysis and methanogenesis $[28,29]$.

Considering the novelty of the study, a synthetic MLL was used in order to ensure repeatability of the experiment; in fact, the use of a real leachate would have required its storage for the entire duration of the experiment and, therefore, its characteristics could have changed. Moreover, because the objective of this research was to assess in a preliminary manner the potential application of the proposed integrated process and to gather the information needed for the design of the following research step, its composition was simplified considering only major leachate components $[15,16]$.

The experiment consisted of two phases: first, metals in the synthetic MLL were removed through granular active materials; then, pre-treated MLL was fed in an AD process as a nutrient additive along with cellulose as a model of a carbon-rich substrate. Moreover, cellulose does not contain any nitrogen and, therefore, it is the worst case possible with respect to the need for N integration by pre-treated MLL. In this manner, it is easier to determine how the presence of MLL affects the digestion process. By comparison, the use of a simple substrate such as cellulose, although useful at the beginning of this 
research, may limit the validity of the results and, therefore, they have to be considered to be preliminary and confirmation using a more complex matrix as substrate is needed.

The significance of this study lies in the possibility of closing the cycle of MLL treatment because methane produced in AD can generate energy, which can partially compensate for the impacts of uncontrolled landfill gas emissions [30], and digestate can replace fertilizers due to the presence of nitrogen and HSs deriving from the pre-treated MLL [31,32]. To the best of the authors' knowledge, neither the application of active filtration to MLLs nor the full integration of this physical-chemical process with the biological phase of leachate treatment have been previously investigated.

\section{Materials and Methods}

\subsection{Synthetic MLL}

The synthetic MLL was prepared following the typical composition described in the literature $[3,33,34]$ by dissolving specific quantities of the reagents indicated in Table 1 into distilled water in order to reach the desired final concentration $(C)$. The choice of the three heavy metals was dictated by their respective ability to activate the different removal mechanisms associated with the use of ZVI [35]. The $\mathrm{pH}$ of the synthetic solution was adjusted to the desired value of 8 with some drops of hydrochloric acid (Sigma-Aldrich, 37\%).

Table 1. Synthetic MLL composition used in column tests.

\begin{tabular}{ccc}
\hline Element & Reagent & $\mathrm{C}[\mathrm{mg} / \mathrm{L}]$ \\
\hline $\mathrm{Cu}^{2+}$ & $\mathrm{CuCl}_{2}$, Sigma-Aldrich (purity $\left.\geq 99.99 \%\right)$ & 2 \\
$\mathrm{Ni}^{2+}$ & $\mathrm{NiCl}_{2} \cdot 6 \mathrm{H}_{2} \mathrm{O}$, Alfa Aesar (purity $\left.=99.95 \%\right)$ & 2 \\
$\mathrm{Zn}^{2+}$ & $\mathrm{ZnCl}_{2}$, Fluka (purity $\left.>98 \%\right)$ & 5 \\
$\mathrm{NH}_{4}{ }^{+}$ & $\mathrm{NH}_{4} \mathrm{Cl}$, Acros Organics (purity $\left.>99 \%\right)$ & 900 \\
$\mathrm{Cl}^{-}$ & see the reagents above & 3100 \\
$\mathrm{COD}$ & $90 \%$ of humic acids, Haifa Italia & 3500 \\
\hline
\end{tabular}

\subsection{Pre-Treatment Tests}

The MLL pre-treatment was simulated in columns (polymethyl methacrylate (PMMA) Plexiglas, internal diameter and height of $5 \pm 0.1$ and $50 \mathrm{~cm}$, respectively) filled with two different granular active materials. Both columns were fed with the synthetic MLL by a peristaltic pump (Watson Marlow 205S) under a constant upward flow of $0.68 \mathrm{~mL} / \mathrm{min}$, which is equivalent to $0.5 \mathrm{~m}^{3}$ /day of leachate per $\mathrm{m}^{2}$ of granular filter. One column was filled with a granular mixture of $\mathrm{ZVI} /$ lapillus at a weight ratio of 20:80, whereas the other contained a granular mixture of ZVI/GAC at a weight ratio of 40:60 [15-17]. In both columns, the ZVI mass was fixed at $300 \mathrm{~g}$, and the amount of the admixing agent (1200 $\mathrm{g}$ of lapillus and $450 \mathrm{~g}$ of GAC, respectively) was chosen on the basis of previous experiments [15-17] and in order to completely fill the columns. The final weight ratios were 20:80 and 40:60 for the ZVI/lapillus and ZVI/GAC columns, respectively. ZVI is a material that can be produced from scrap iron (e.g., from the automotive industry); lapillus is a volcanic material that is available worldwide and can be also produced as a by-product of the pumice extraction; and, finally, GAC is a material whose properties are well known and it is not particularly expensive.

The ZVI used was type FERBLAST RI 850/3.5, distributed by Pometon S.p.A. (Mestre, Italy) and mainly composed of iron (>99.74\%). The granular lapillus was distributed by SEM s.r.1. (Viterbo, Italy) and mainly consisted of silica (47\%) and the oxides of various elements as follows: $\mathrm{Al}_{2} \mathrm{O}_{3}=15 \%, \mathrm{~K}_{2} \mathrm{O}=8 \%, \mathrm{Na}_{2} \mathrm{O}=1 \%, \mathrm{Fe}_{2} \mathrm{O}_{3} / \mathrm{FeO}=7-8 \%, \mathrm{MnO}=0.15 \%$, $\mathrm{MgO}=5.5 \%$, and $\mathrm{CaO}=11 \%$. Before the column tests, a wet gradation was carried out on the lapillus in order to obtain a particle size distribution similar to that of ZVI. To do that, lapillus grains both retained on sieve No. $20(>0.84 \mathrm{~mm})$ and passed through sieve No. $200(<0.074 \mathrm{~mm}$ ) were removed. Lastly, GAC (type CARBOSORB 2040) was provided by Comelt s.r.l. (Milan, Italy). Furthermore, the size of GAC particles was similar to those of ZVI $(0.85-0.425 \mathrm{~mm})$. In the Supplementary Materials (Table S1), the coefficient of uniformity $\left(\mathrm{U}=\mathrm{d}_{60} / \mathrm{d}_{10}\right.$, i.e., the ratio between the diameters corresponding to $60 \%$ and 
$10 \%$ finer grain size distributions, respectively), mean grain size $\left(\mathrm{d}_{50}\right.$, i.e., the diameters corresponding to $50 \%$ finer grain size distribution), and particle density $(\rho)$ of the reactive granular materials are summarized.

A sampling port located at the top of the columns $(50 \mathrm{~cm})$ was used to sample the MLL filtered through the active medium during the test period through a $10 \mathrm{~mL}$ syringe. The $\mathrm{pH}$ of MLL samples was measured, and they were then analyzed for ammonium, chloride, and COD concentrations using specific pre-dosed cuvettes (Merck Millipore Ammonium Cell Test 114559, Chloride Cell Test 114730, and COD Cell Test 114555, respectively) using a photometer (WTW Photolab S12), and $\mathrm{Cu}, \mathrm{Ni}$, and $\mathrm{Zn}$ were evaluated by ICP-OES (Perkin Elmer OPTIMA 8000) in accordance with other reports [36]. The removal efficiency $\left(R_{E}\right)$ of contaminants was calculated using Equation (1), where $C_{\text {in }}$ and $C_{\text {out }}$ stand for, respectively, the concentration $(\mathrm{mg} / \mathrm{L})$ of the contaminant in the input and output from the column.

$$
\mathrm{R}_{\mathrm{E}}=\frac{\mathrm{C}_{\text {in }}-\mathrm{C}_{\text {out }}}{\mathrm{C}_{\text {in }}} \cdot 100
$$

Pre-treated MLLs, which came out from the columns, were separately collected and stored at $4{ }^{\circ} \mathrm{C}$ before their use in $\mathrm{AD}$ tests. The column tests were stopped after 38 days of continuous operation. The amount of leachate treated was equivalent to about $10.5 \mathrm{~m}^{3} \mathrm{MLL} / \mathrm{m}^{3}$ Filter_material.

\subsection{Semicontinuous $A D$ Tests}

The purpose of this part of the experiment was to evaluate the use of the pre-treated MLLs, derived from the two column tests, as nutrient solutions for anaerobic digestion. For each column, a composite MLL sample was made by mixing weekly samples coming from the respective column outputs. The composition of the two composite samples used in the AD tests is summarized in Table 2.

Table 2. Synthetic MLL composition used in column tests.

\begin{tabular}{ccc}
\hline & \multicolumn{3}{c}{ Pre-Treated Leachate } \\
& ZVI/Lapillus $\mathbf{2 0 : 8 0}$ & ZVI/GAC 40:60 \\
\hline $\mathrm{pH}$ & 7.5 & 7.1 \\
$\mathrm{COD}[\mathrm{mg} / \mathrm{L}]$ & 2363 & 1533 \\
$\mathrm{NH}_{4}-\mathrm{N}[\mathrm{mg} / \mathrm{L}]$ & 838.7 & 827.3 \\
$\mathrm{Cl}^{-}[\mathrm{mg} / \mathrm{L}]$ & 3067 & 3013 \\
$\mathrm{Cu}[\mathrm{mg} / \mathrm{L}]$ & 0.30 & 0.41 \\
$\mathrm{Ni}[\mathrm{mg} / \mathrm{L}]$ & 0.52 & 0.55 \\
$\mathrm{Zn}[\mathrm{mg} / \mathrm{L}]$ & 1.64 & 0.97 \\
\hline
\end{tabular}

As already mentioned, metals and ammonium can be stimulatory to anaerobic microorganisms if present in adequate concentrations [23,37]. The presence of residual ammonium, $\mathrm{Cu}, \mathrm{Ni}$, and $\mathrm{Zn}$ makes pre-treated MLL analogous to the UNI/TS11703:2018 nutrient solutions (Italian norm for $\mathrm{AD}$ tests) prepared with $\mathrm{CuCl}_{2}, \mathrm{NiCl}_{2} \cdot 6 \mathrm{H}_{2} \mathrm{O}, \mathrm{ZnCl}_{2}$, and other metal compounds. Similarly, ammonia can be toxic or beneficial to anaerobic microorganisms depending on its concentration [37].

The semicontinuous AD tests were carried out in four identical reactors (Figure S1) designated as A, B, C, and D. In each reactor, microbial inoculum, distilled water as the diluting medium, pure cellulose as the organic substrate, and MLL as the nutrient solution were employed. In particular, reactors A and B were fed with MLL coming from the $\mathrm{ZVI} /$ lapillus column, whereas the MLL added to reactors $\mathrm{C}$ and $\mathrm{D}$ was the output from the ZVI/GAC pre-treatment column.

The inoculum used in the experiment was a liquid digestate from a full-scale AD plant that treats manure and various residues from the agro-industry. As soon as the digestate was collected, it was sieved in order to remove fibrous materials (e.g., straw) and then stored in anaerobic conditions at $35{ }^{\circ} \mathrm{C}$ to reduce the nonspecific biogas production as much as possible. 
$\alpha$-Cellulose (CAS 9004-34-6, Sigma-Aldrich, St. Louis, MO, USA) was used as the organic substrate due to its well-defined composition (only glucose as the monomer). Furthermore, it is an easily biodegradable material that stabilizes the AD process with a predictable methane production [21].

Inoculum and substrate were characterized according to standard methods [38] (see Supplementary Materials, Table S2).

Semicontinuous reactors consisted of three-neck bottles with 1.1 L volume (WTW-Germany), which were equipped with valves allowing biogas collection, substrate and MLL feeding, and sludge withdrawal. Biogas was collected from one of the valves connected to a tube placed in the headspace, while, with the biogas valve closed, a syringe was connected to the second one (feeding valve) connected to a tube immersed in the sludge, allowing excess sludge withdrawal and finally the feeding of a mixture containing dilution water, substrate and MLL. Because digestion was carried out in mesophilic conditions, the reactors were placed in a thermostatic cabinet at $35 \pm 0.5^{\circ} \mathrm{C}$ and mixed using a magnetic stirrer throughout the test period.

The total operational volume per reactor was $600 \mathrm{~mL}$. At the beginning of the tests, the reactors were loaded with inoculum and distilled water in order to reach the desired total solids (TS) content of the mixture, which was set at $4 \%$. Cellulose was fed into the reactors two times per week at an organic loading rate (OLR) of $1.0 \mathrm{gVS} / \mathrm{L} \cdot$ day $(1.25 \mathrm{gCOD} / \mathrm{L} \cdot$ day $)$ throughout the duration of the experiment; the feeding schedule was derived from previous experiments $[39,40]$. The hydraulic residence time (HRT) was set at 20 days for the first week (bacteria acclimatation period), and then at 10 days for the remaining part of the experiment, because cellulose degradation is quite fast.

As already mentioned, two times per week, generated biogas was slowly transferred into an alkaline trap, which was a second bottle containing $1 \mathrm{~L}$ of a $3 \mathrm{M} \mathrm{NaOH}$ solution, using a $100 \mathrm{~mL}$ syringe. In this manner, the carbon dioxide present in the biogas was absorbed in the alkaline solution, whereas methane caused a pressure increase in the trap and provoked the displacement of an equivalent volume of solution [39]. Due to the $\mathrm{pH}$ reduction, $4 \mathrm{~g}$ of $\mathrm{NaHCO}_{3}$ was added to each reactor on days 20 and 27, whereas for reactor A only, feeding was suspended on day 27 because the biogas production was inhibited.

Because it was decided to test two different $\mathrm{COD} / \mathrm{NH}_{4}-\mathrm{N}$ ratios per type of MLL (50 and 25, i.e., acceptable and low ratios, respectively, according to [41], different amounts of pre-treated MLLs were used to dilute cellulose along with distilled water. The semicontinuous reactor experimental program is summarized in Table 3. The AD tests were stopped on day 38 (3 HRT).

Table 3. Semicontinuous reactors' program.

\begin{tabular}{ccccccc}
\hline Reactor & Leachate & COD/NH $\mathbf{- N}$ & $\begin{array}{c}\text { Week I (Acclimation) } \\
\text { Pre-Treated } \\
\text { Leachate }[\mathbf{m L} / \mathbf{d}]\end{array}$ & $\begin{array}{c}\text { Week II-VI (Regime Phase) } \\
\text { Dilution Water } \\
{[\mathbf{m L} / \mathbf{d}]}\end{array}$ & $\begin{array}{c}\text { Pre-Treated } \\
\text { Leachate }[\mathbf{m L} / \mathbf{d}]\end{array}$ & $\begin{array}{c}\text { Dilution Water } \\
{[\mathbf{m L} / \mathbf{d}]}\end{array}$ \\
\hline A & ZVI/lapillus & 25 & 35.8 & 0.0 & 35.8 & 24.2 \\
$\mathrm{~B}$ & ZVI/lapillus & 50 & 17.9 & 12.1 & 17.9 & 42.1 \\
$\mathrm{C}$ & ZVI/GAC & 25 & 36.3 & 0.0 & 36.3 & 23.7 \\
$\mathrm{D}$ & ZVI/GAC & 50 & 18.1 & 11.9 & 18.1 & 41.9 \\
\hline
\end{tabular}

During the semicontinuous experiments, the $\mathrm{pH}$ of the digestate extracted from reactors was measured twice per week, whereas TS, volatile solids (VS), COD, $\mathrm{NH}_{4}-\mathrm{N}$, and volatile fatty acids (VFAs) were determined on average weekly digestate samples. The $\mathrm{pH}$, TS, and VS of raw digestates were determined according to standard methods [38]. COD, $\mathrm{NH}_{4}-\mathrm{N}$, and VFAs analyses were carried out on the liquid fractions resulting from digestate centrifugation (10,000 rpm for $10 \mathrm{~min}$ ). The former two parameters were calculated using pre-dosed cuvettes (Merck Millipore COD Cell Test 114,555 and Ammonium Cell Test 114,559, respectively) and photometric determination (WTW Photolab S12), whereas VFAs were determined through a three-point titration of $20 \mathrm{~mL}$ of liquid digestate sample with $0.1 \mathrm{~N}$ sulfuric acid at $\mathrm{pH} 5.0,4.3$, and 4.0 [42,43]. An immersed electrode allowed 
for $\mathrm{pH}$ measurement, and the volumes of the added titrants were recorded. Total VFA concentration was calculated as follows:

$$
\text { Total VFA }\left[\mathrm{mg} \cdot \mathrm{L}^{-1}\right]=\left[131340 \cdot\left(\mathrm{V}_{\mathrm{pH}_{4.0}}-\mathrm{V}_{\mathrm{pH}_{5.0}}\right) \cdot \frac{\mathrm{N}_{\mathrm{H}_{2} \mathrm{SO}_{4}}}{\mathrm{~V}_{\text {sample }}}\right]-\left[3.08 \cdot \mathrm{V}_{\mathrm{pH}_{4.3}} \cdot \frac{\mathrm{N}_{\mathrm{H}_{2} \mathrm{SO}_{4}}}{\mathrm{~V}_{\text {sample }}} \cdot 1000\right]-10.9
$$

where $\mathrm{V}_{\mathrm{pH}_{4.0}}$ is the volume in $\mathrm{mL}$ of added solution until $\mathrm{pH}=4.0$ was reached, $\mathrm{V}_{\mathrm{pH}_{4.3}}$ is the volume in $\mathrm{mL}$ of added solution until $\mathrm{pH}=4.3$ was reached, $\mathrm{V}_{\mathrm{pH}_{5.0}}$ is the volume in $\mathrm{mL}$ of added solution until $\mathrm{pH}=5.0$ was reached, $\mathrm{V}_{\text {sample }}$ is the volume in $\mathrm{mL}$ of the sample $\left(20 \mathrm{~mL}\right.$ ), and $\mathrm{N}_{\mathrm{H}_{2} \mathrm{SO}_{4}}$ is the normality of the acid solution (0.1).

\section{Results and Discussion}

\subsection{Pre-Treatment Tests}

The $\mathrm{pH}$ values were measured in samples withdrawn from both columns at three sampling ports $(5,28$, and $50 \mathrm{~cm}$ ) on days 3 and 7 (see Supplementary Materials, Table S3). After the first week, $\mathrm{pH}$ stabilized at the influent value of about 8 for the whole duration of the tests.

Ammonium, chloride, and COD concentrations were measured in MLL samples withdrawn at the outlet of the columns. The results, which are the average of two replicates, are summarized in Table 4 for the column tests carried out with the ZVI/lapillus and ZVI/GAC granular reactive media, respectively.

Table 4. Ammonium, chloride, and COD concentrations in MLLs coming from ZVI/lapillus and ZVI/GAC columns.

\begin{tabular}{|c|c|c|c|c|c|c|}
\hline \multirow[b]{2}{*}{ Day } & \multicolumn{3}{|c|}{ ZVI/Lapillus Column } & \multicolumn{3}{|c|}{ ZVI/GAC Column } \\
\hline & Ammonium $[\mathrm{mg} / \mathrm{L}]$ & Chloride $[\mathrm{mg} / \mathrm{L}]$ & COD $[\mathrm{mg} / \mathrm{L}]$ & Ammonium [mg/L] & Chloride $[\mathrm{mg} / \mathrm{L}]$ & $\mathrm{COD}[\mathrm{mg} / \mathrm{L}]$ \\
\hline $\begin{array}{l}\text { Input } \\
\text { leachate }\end{array}$ & $911 \pm 1$ & $3060 \pm 20$ & $3535 \pm 35$ & $912 \pm 14$ & $3120 \pm 40$ & $3450 \pm 30$ \\
\hline 2 & $395 \pm 3$ & $2880 \pm 40$ & $1455 \pm 35$ & $158 \pm 14$ & $3220 \pm 20$ & $1220 \pm 60$ \\
\hline 8 & $898 \pm 14$ & $3100 \pm 20$ & $3475 \pm 15$ & $923 \pm 13$ & $3100 \pm 20$ & $2200 \pm 10$ \\
\hline 14 & $897 \pm 11$ & $3220 \pm 20$ & $3335 \pm 5$ & $934 \pm 26$ & $3180 \pm 20$ & $2520 \pm 10$ \\
\hline 23 & $900 \pm 0$ & $3080 \pm 0$ & $3355 \pm 5$ & $924 \pm 30$ & $3140 \pm 20$ & $2835 \pm 25$ \\
\hline 38 & $887 \pm 1$ & $3100 \pm 20$ & $3435 \pm 5$ & $897 \pm 5$ & $3120 \pm 0$ & $2785 \pm 25$ \\
\hline
\end{tabular}

In general, the removal of ammonium and chloride was basically negligible for both granular media. Ammonium content decreased in the first days of operation in both pretreated MLLs, with the removal efficiency for the ZVI/GAC granular medium being better than that for the ZVI/lapillus mixture ( $83 \%$ and $57 \%$, respectively). From day 8 onward, the amount of ammonium in the MLLs was close to the influent concentration. GAC was not expected to help with ammonium removal $[15,44]$ due to its nonpolar surface, which results in poor interactions with polar adsorbates [45]. Nevertheless, it was noticeable that ZVI mixed with GAC showed a better performance compared to the ZVI/lapillus mixture $\left(R_{E}=57 \%\right)$, even if only for a short period of time. Chloride was also basically unaffected by pre-treatment.

COD concentration measured after 2 days witnessed a decrease in both tests $\left(R_{E}\right.$ of $59 \%$ and $65 \%$ for ZVI/lapillus and ZVI/GAC column, respectively), whereas during the tests, it was slightly removed only by the ZVI/GAC granular mixture due to the key role played by the presence of GAC. Indeed, GAC is known as an effective adsorbent for organic matter [18], and its application is common in leachate treatment research [16,46-48]. In general, as [49] asserted, the application of activated carbon adsorption is effective for the removal of organic compounds from MLL but not for ammonia nitrogen.

On the contrary, lapillus was found not to be a suitable material for ammonium, chloride, and COD removal. This proves that lapillus has no interactions with these tested contaminants, although they were not the specific targets of the pre-treatment.

Metal removal, at the outlet of the columns, is shown in Figure 1. After 2 days of operation, metal removal in the ZVI/lapillus filter was almost complete with an efficiency close to $100 \%$ for the three metals. Subsequently, the removal efficiency toward Cu was 
slightly reduced assuming values between $84 \%$ and $93 \%$ until the end of the test. The reductions in $\mathrm{Ni}$ and $\mathrm{Zn}$ were more noticeable; for the former, it was in the range 55-67\%, while for the latter, it gradually decreased from $61 \%$ on day 8 to $36 \%$ on day 38 .
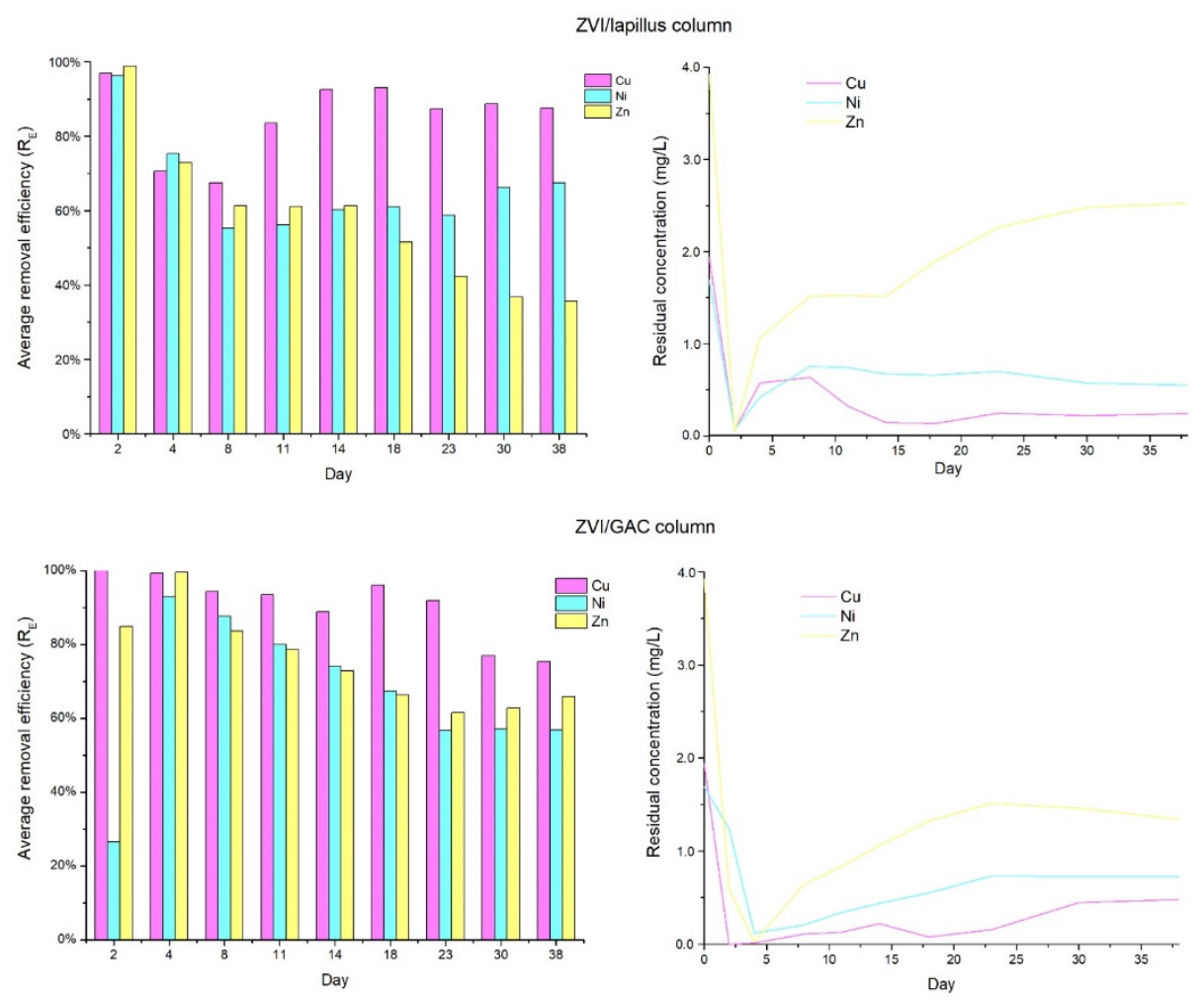

Figure 1. $\mathrm{Cu}, \mathrm{Ni}$, and $\mathrm{Zn}$ removals in $\mathrm{ZVI} /$ lapillus and ZVI/GAC columns.

Referring to the column filled with the ZVI/GAC mixture, $\mathrm{Cu}$ was completely removed at the beginning of the test $\left(\mathrm{R}_{\mathrm{E}}\right.$ of about $\left.100 \%\right)$. Its removal efficiency was reduced only in the last days of the test, assuming the lowest value of $75 \%$ on day 38 . Ni removal was scarce until day $2\left(R_{E}=27 \%\right)$ but significant on day $4\left(R_{E}=93 \%\right)$. From this point, the removal efficiency toward Ni progressively decreased to $57 \%$ on day 38 . Lastly, Zn removal efficiency increased to almost $100 \%$ until day 4 , before gradually decreasing from $84 \%$ on day 8 to $66 \%$ on day 38 .

In general, the results showed that both granular filters were efficient in removing the three contaminants according to the following sequences for ZVI/lapillus and ZVI/GAC granular mixtures, respectively: $\mathrm{Cu}>\mathrm{Ni}>\mathrm{Zn}$ and $\mathrm{Cu}>\mathrm{Zn}>\mathrm{Ni}$.

ZVI was expected to remove HMs through a mechanism of reduction, adsorption onto its corrosion products, and precipitation and coprecipitation with its precipitating oxides [50,51]. Cu was removed via the well-described cementation process, whereas $\mathrm{Ni}$ and $\mathrm{Zn}$ removal relied on adsorption onto ZVI corrosion products and coprecipitation with $\mathrm{ZVI}$ oxides. Thus, the processes were facilitated by low $\mathrm{pH}$ values. Because, in these tests, an alkaline solution was used, it can be supposed that ZVI corrosion was slowed. However, this may imply the functionality of the filter for a longer period of time.

The role of GAC in HMs removal from leachate is well known [19]. For instance, its removal efficiency was tested by [52] for solutions with $\mathrm{pH}$ ranging from 6.0 to 7.7 with the removal of several HMs $\left(\mathrm{Cd}^{(\mathrm{II})}, \mathrm{Cu}^{(\mathrm{II})}, \mathrm{Cr}^{(\mathrm{III})}, \mathrm{Mn}^{(\mathrm{II})}, \mathrm{Pb}^{(\mathrm{II})}\right.$, and $\left.\mathrm{Zn}^{(\mathrm{II})}\right)$ in the range of $80-96 \%$ at an initial concentration of $184 \mathrm{mg} / \mathrm{L}$. GAC can remove HMs through sorption on its porous surface, and through both surface and pore precipitation [53,54]. Moreover, sorption can also occur with organic matter because HMs in landfill leachate are thought to form complexes with it [55]. 
Similarly, lapillus is expected to remove HMs ions from aqueous solution via adsorption, as demonstrated in previous studies $[17,51,56]$.

$\mathrm{Cu}$ was, as expected, the metal most easily removed by both filters (Figure 1 ). The $\mathrm{ZVI} / \mathrm{GAC}$ filter performed slightly better than the ZVI/lapillus-filled column with $\mathrm{R}_{\mathrm{E}}$ values of $91 \%$ and $85 \%$ on average, respectively. Similar results in terms of removal efficiency were reported by [15] for a ZVI/GAC mixture (weight ratio 30:70 and $225 \mathrm{~g}$ of ZVI) but considering an acid leachate $(\mathrm{pH}=5)$ and a longer residence time (flow rate of $0.1 \mathrm{~mL} / \mathrm{min}$ ).

Ni removal had an almost identical efficiency ( $66 \%$ and $67 \%$ on average) for both filters. However, the ZVI/lapillus-filled column removed $\mathrm{Ni}$ with a more regular trend compared to the ZVI/GAC filter (Figure 1). Ni removal was far more efficient in [15] where a ZVI/GAC granular mixture was tested toward an acid leachate (removal efficiency ranged from $93 \%$ to $80 \%$ ). This behavior can be attributed to the aforementioned more favorable conditions for iron corrosion.

Lastly, the main difference between the two columns was exhibited on account of $\mathrm{Zn}$ removal. In fact, the ZVI/GAC granular mixture removed Zn better than the ZVI/lapillus filter with efficiencies of $75 \%$ and $58 \%$ on average, respectively. As in the case of $\mathrm{Ni}, \mathrm{Zn}$ removal performance was considerably better for the ZVI/GAC filter studied by [15] ( $R_{\mathrm{E}}$ ranged from $98 \%$ to $95 \%$ using an acid leachate) confirming the better aptitude of the filter for the treatment of acidic solutions due to iron corrosion. Nevertheless, the metal removal sequence of this test $(\mathrm{Cu}>\mathrm{Ni}>\mathrm{Zn})$ was in accordance with that of [15].

All results considered, the ZVI/GAC granular filter had a slightly better metal removal performance than the ZVI/lapillus granular mixture for MLL treatment. The aptitude of GAC for effective metal removal in alkaline conditions supported the ZVI, which performs better with acidic leachate. On the contrary, lapillus seemed less efficient in sufficiently supporting ZVI with metal removal; however, it is far cheaper because it is widely available and often produced as a by-product of pumice extraction, which is a significant advantage for its practical use.

\subsection{Semicontinuous $A D$ Tests}

As shown in Table 2, the composite samples of MLL pre-treated by ZVI/lapillus and ZVI/GAC mixtures had very similar compositions in terms of $\mathrm{pH}$, in addition to ammonium, chloride, $\mathrm{Cu}$, and $\mathrm{Ni}$ concentrations. Conversely, $\mathrm{COD}$ and $\mathrm{Zn}$ concentrations were lower in the pre-treated MLL derived from the ZVI/GAC column.

Maximum concentrations of HMs and chloride were calculated for each reactor, according to the MLLs and water volumes added from the second week onward (Table 5), under the reasonable hypothesis that HMs and chloride were conserved (i.e., unaffected by the process).

Table 5. Maximum concentration of HMs and chloride in feeding volumes.

\begin{tabular}{ccccc}
\hline & & \multicolumn{2}{c}{$\mathbf{C}_{\max }[\mathrm{mg} / \mathbf{L}]$} & \\
Reactor & $\mathbf{C u}$ & $\mathbf{N i}$ & $\mathbf{Z n}$ & Chloride \\
\hline $\mathrm{A}$ & 0.18 & 0.31 & 0.98 & 1828.3 \\
$\mathrm{~B}$ & 0.09 & 0.16 & 0.49 & 914.1 \\
$\mathrm{C}$ & 0.25 & 0.33 & 0.59 & 1821.1 \\
$\mathrm{D}$ & 0.12 & 0.17 & 0.29 & 910.6 \\
\hline
\end{tabular}

In the case of $\mathrm{HMs}$ and chloride, concentrations in the $\mathrm{AD}$ tests were far lower than the inhibitory thresholds, which were found to be 500,100 , and $50 \mathrm{mg} / \mathrm{L}$ for $\mathrm{Cu}, \mathrm{Ni}$, and Zn [25], respectively, and 4-9 g/L for chloride [57]. For reactors B and partially D the HMs maximum expected concentrations already complied with the Italian discharge limits for soil (Legislative Decree 152/2006; Cu $<0.1 \mathrm{mg} / \mathrm{L}$; Ni $<0.2 \mathrm{mg} / \mathrm{L} ; \mathrm{Zn}<0.5 \mathrm{mg} / \mathrm{L}$ ). In a full-scale application, an appropriate dosage and/or and earlier replacement of the filter material used in the pretreatment can be considered in order to fully comply with the standard required for the intended use of digestate. The use of a cheap admixing 
agent for the ZVI (i.e., the lapillus) may, in this case, reduce the cost of the replacement. Similarly, it can be stated that the low amounts added, in addition to the dilution with water and inoculum, would significantly reduce the concentration of persistent contaminants eventually present in $\mathrm{AD}$ reactors (e.g., pharmaceuticals and microplastics).

The $\mathrm{pH}$ trends of each semicontinuous reactor during the $\mathrm{AD}$ processes are depicted in Figure 2. During the semicontinuous AD tests, the $\mathrm{pH}$ of all reactors decreased from an initial value of around 7.8, showing similar trends to those during the $\mathrm{AD}$ tests. The lowest value (6.2) was reached in reactor A on day 20, probably due to an accumulation of VFAs. On days 20 and 27, $4 \mathrm{~g}$ of $\mathrm{NaHCO}_{3}$ was added to all reactors in order to buffer the $\mathrm{pH}$. As a result, a peak of 7.7 was measured on day 30 in reactor A. At the end of the tests, all reactors exhibited a $\mathrm{pH}$ of 6.9, except for reactor $\mathrm{A}$ (6.7). Despite the decreasing trends, the $\mathrm{pH}$ did not reach inhibitory values for methanogenic bacteria. However, the very irregular $\mathrm{pH}$ trend in reactor A could possibly hint at process imbalance.

Methane yields and cumulative methane productions for each reactor are depicted in Figure 2. Reactor A exhibited a gradually growing methane production up to $0.3 \mathrm{NL} / \mathrm{gVS}_{\text {added }}$ (days 16-20) when methane production abruptly stopped. Reactor B reached the highest methane yield ( $0.37 \mathrm{~L}$ of methane per grams of VS added) after the first week of operation. From days 10 to 30, methane yield was fairly stable, remaining between 0.22 and $0.30 \mathrm{NL} / \mathrm{gVS}_{\text {added }}\left(0.26 \mathrm{NL} / \mathrm{gVS}_{\text {added }}\right.$ on average). During the last week of operation, methane production sharply decreased to $0.06 \mathrm{NL} / \mathrm{gVS}_{\text {added }}$ on the last day of the test. Reactor $\mathrm{C}$ showed a trend similar to reactor $\mathrm{B}$ but with lower methane yield values. The maximum $\left(0.27 \mathrm{NL} / \mathrm{gVS}_{\text {added }}\right)$ was measured on day 13 , before production gradually decreased. In reactor $\mathrm{D}$, no considerable methane yield variations were measured. Indeed, methane yield remained close to $0.1 \mathrm{NL} / \mathrm{gVS}_{\text {added }}$ for almost the entire test duration.

Cumulative methane productions of the four reactors were compared to that of the ideal AD of pure cellulose. The latter was determined by accounting for the cellulose biomethanation potential of $335 \mathrm{NmL} / \mathrm{gVS}( \pm 25 \%)$ reported on the basis of the aforementioned UNI/TS 11703:2018 norm. After 38 days, the complete digestion of pure cellulose would have generated $7.2 \mathrm{NL}$ of methane on average.

During the first 2 weeks of operation, the methane amount produced by reactor B process was consistent with the expected production from the complete conversion of cellulose, whereas at the end of the test, the final cumulative methane production was about $5.3 \mathrm{NL}$; in fact, this reactor was the best performing, with a final production equal to about $75 \%$ of the expected one. Reactor $C$ was the second-best process in terms of the cumulative volume of methane produced, with a final value of about 4.1 NL and a production close to that of reactor B for the first 4 weeks. Reactor A reached a final methane production of $2.0 \mathrm{NL}$ on day 16, as, from that point onward, methane generation was null. Conversely, reactor $\mathrm{D}$ generated methane throughout the experiment, despite maintaining low yields, achieving 1.6 NL of total methane production.

The analysis of average weekly digestates collected from the four reactors is summarized in Tables S4 and S5 (Supplementary Materials) and Figure 3.

Both TS and VS trends were similar among digestates and decreased during the tests in each reactor. Considering the initial TS value of each reactor mixture (4\%), solid matter was scarcely consumed by the microbial community during the first week of operation, whereas the solid content decreased from the second week onward. At the end of the tests, TS reached values of $0.6-0.8 \%$. VS remained almost constant for the first 3 weeks of tests in all reactors before their presence sharply decreased. The abrupt and abnormal reduction in VS/TS from week 4 onward hints at a reduction in microbial activity in the reactors as discussed below. 

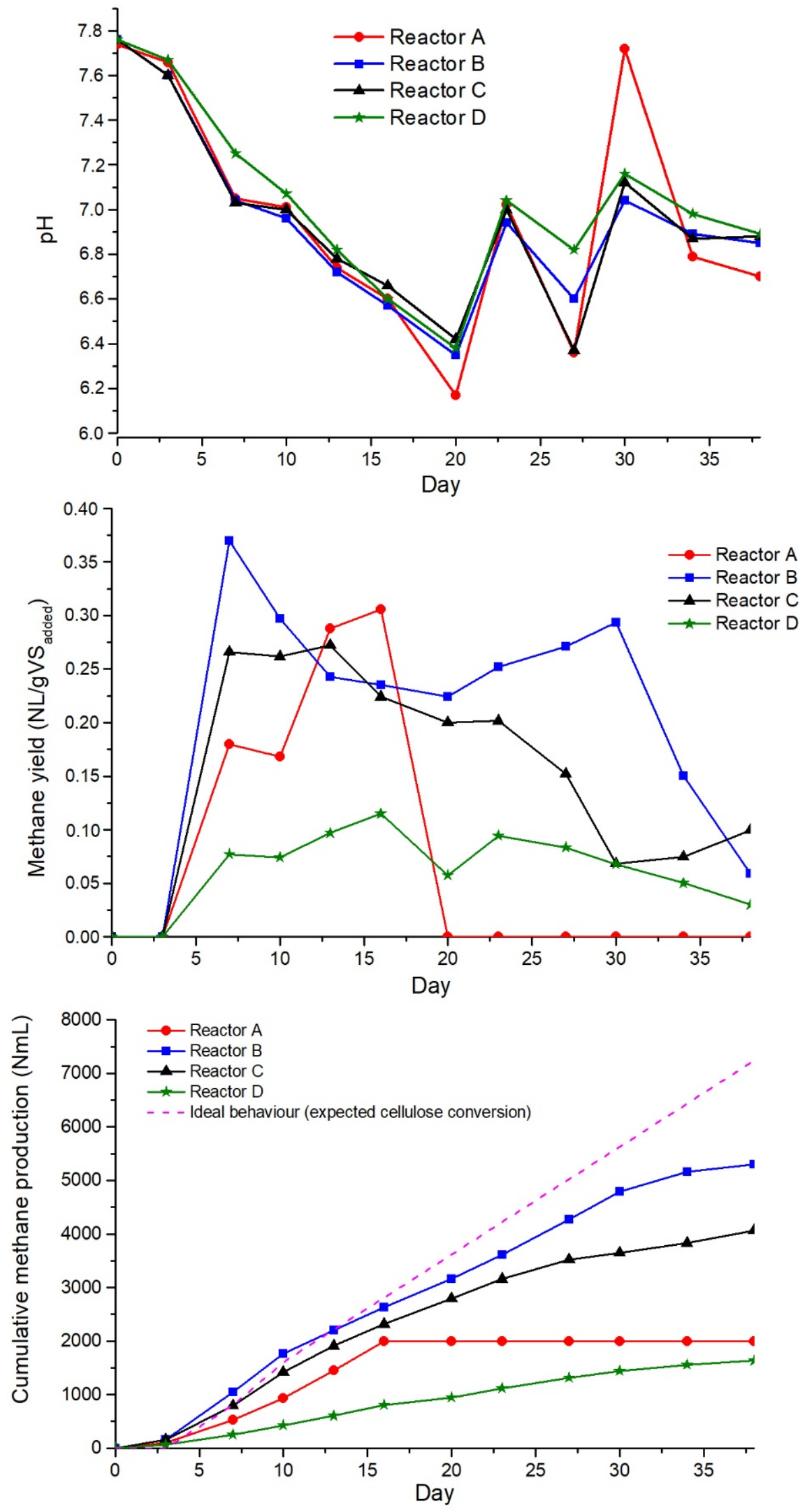

Figure 2. Anaerobic reactors $\mathrm{pH}$ trends, methane yields, and cumulative methane productions. 

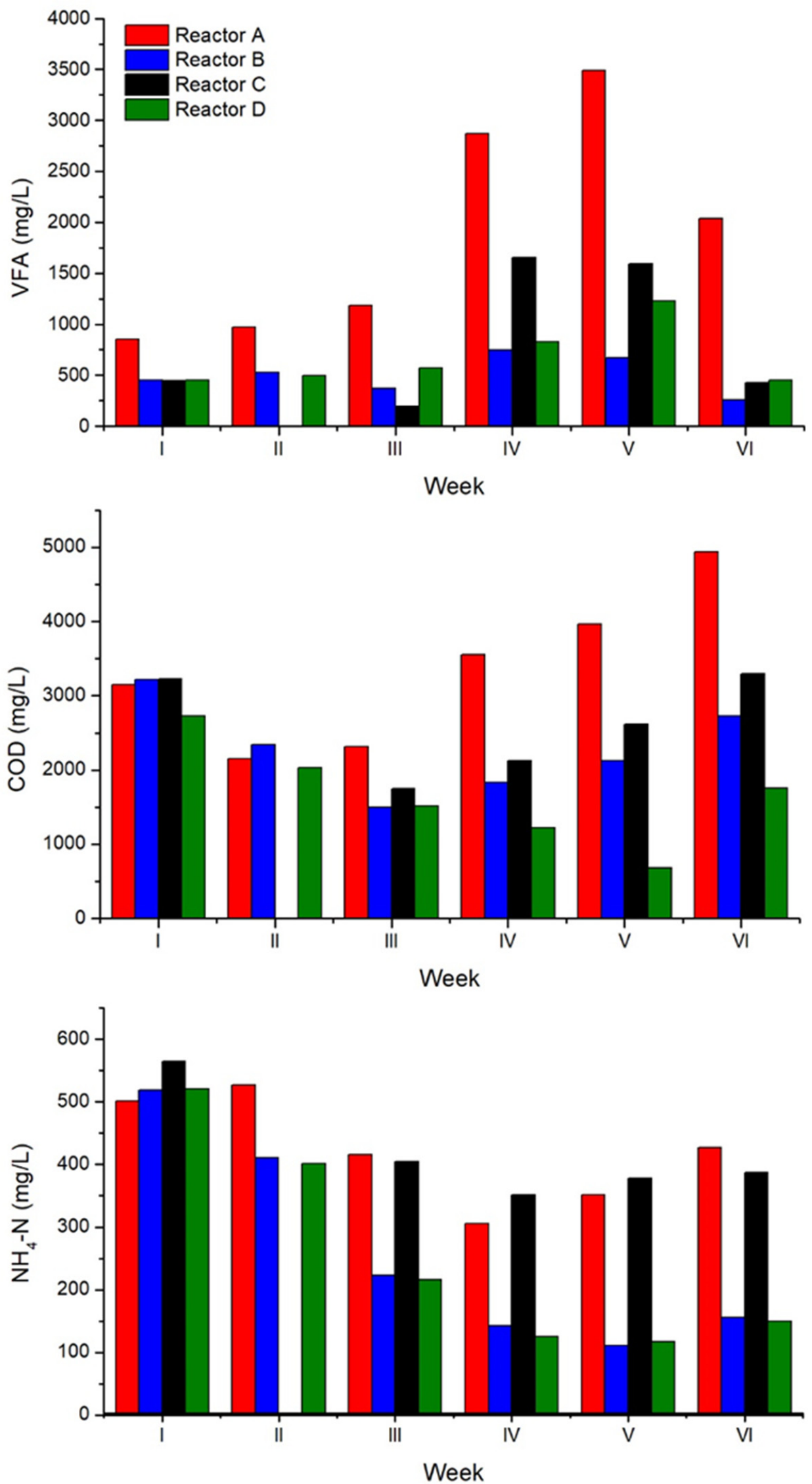

Figure 3. VFAs, $\mathrm{COD}$, and $\mathrm{NH}_{4}-\mathrm{N}$ contents in weekly collected digestates. 
During the first and second weeks of the tests, the highest contents of VFAs (852 and $975 \mathrm{mg} / \mathrm{L}$, respectively) were recorded in reactor $\mathrm{A}$, whereas those in reactors $\mathrm{B}, \mathrm{C}$, and $D$ were similar (data for reactor $C$ from the second week were not recorded because of a sampling problem). From week 3 onward, a continuous increase in VFAs was recorded in reactor $\mathrm{A}$, again suggesting a probable imbalance of the process. The VFA concentration reached inhibitory levels from week 4 onward in this reactor. VFAs also increased to a lesser extent in reactors $C$ and D in weeks 4 and 5. The drop in the level of VFAs in week 6 when methane production was already scarce, even in the best-performing reactor (i.e., B), may have been due to a possible inhibition of hydrolysis.

In the centrifuged composite samples from the first week, a COD of about $3200 \mathrm{mg} / \mathrm{L}$ was measured in each reactor. Despite the aforementioned sampling problem for reactor $C$, in the second week, slight decreases in COD content were recorded for all reactors. From the third week onward, COD concentration in reactor A started increasing again, reaching a peak of $4935 \mathrm{mg} / \mathrm{L}$ at the end of the experiment. The COD concentration in reactors $B$ and $C$ increased from the fourth week until the end of the tests, but with lower values compared to reactor A. Conversely, the COD concentration in reactor D smoothly decreased during the digestion, with the lowest value of $680 \mathrm{mg} / \mathrm{L}$ recorded in the fifth week, only increasing in the last week to $1755 \mathrm{mg} / \mathrm{L}$.

The highest $\mathrm{NH}_{4}-\mathrm{N}$ concentrations were recorded in the first week of tests for reactors $\mathrm{B}, \mathrm{C}$, and D $(519,565$, and $521 \mathrm{mg} / \mathrm{L}$, respectively) and in the second week for reactor A $(527 \mathrm{mg} / \mathrm{L})$. In reactor A, ammonium content decreased to 306 in the fourth week, before increasing until the end of the experiment. In other reactors, analogous trends were recorded but with $\mathrm{NH}_{4}-\mathrm{N}$ concentration values, which were lower in reactors $\mathrm{B}$ and $\mathrm{D}$ and similar in reactor $\mathrm{C}$ compared to reactor $\mathrm{A}$. As with HMs and chloride (Table 5), the $\mathrm{NH}_{4}-\mathrm{N}$ content in the AD reactors was lower than the inhibitory threshold $(1.7 \mathrm{~g} / \mathrm{L})$ found in the literature [37,58].

Methane yields and cumulative methane productions depicted in Figure 2 clearly show that, with the exception of reactor D, methane production was not steady; moreover, after an initial production quite close to the "ideal" expected for cellulose, the process showed clear signs of inhibition. This was early and abrupt for reactor A, where after day 16 , methane production totally stopped, whereas it was more delayed for reactor $B$, i.e., the best-performing system, where it was significant and quite steep from day 30 onward. By comparison, inhibition was more gradual in reactor $C$, with a steady and slow decline beginning on day 13 . The behavior of reactor $\mathrm{D}$ was very peculiar, whereby the methane production was very slight but regular throughout the test, equal to approximately $25 \%$ of the "ideal" production expected for pure cellulose. The analysis of trends for $\mathrm{pH}, \mathrm{VFAs}$, and $\mathrm{NH}_{4}-\mathrm{N}$ (Figure 3) did not justify this observation. This behavior could be classified as an "inhibited steady state", i.e., a condition where the process ran stably but with methane yield lower than expected due to limited bacterial activity [37]. The identified inhibition of methanogenesis is most probably not attributable to an excess of metals or chloride (Table 5) or $\mathrm{NH}_{4}-\mathrm{N}$ (Figure 3) because, as already shown, the concentrations of those parameters were well below their respective inhibition thresholds. Ref. [29] reported the inhibition of anaerobic processes (particularly hydrolysis and methanogenesis) due to the presence, as in this case, of noticeable amounts of HSs; moreover, they also stated that the inhibition was irreversible and exacerbated by an increase in the HS/VS ratio. Because the biomass could not adapt to the presence of HSs, the abundance of microorganisms decreased, which is in agreement with the reduction in VS measured for all reactors. According to the same paper, HSs interfere with hydrolytic and methanogenic enzymes.

It is interesting to highlight that the two reactors where methane production was more noticeable (reactor B), or more regular albeit quite scarce (reactor D), were those where the addition of pre-treated synthetic MLL and, thus, of HSs was lower.

On the contrary, reactor A, supplemented with a higher amount of COD-rich pretreated leachate, had a more significant presence of HSs and showed a more abrupt inhibition of AD. 


\section{Conclusions}

The proposed pre-treatment of MLL confirmed the excellent efficiency and selectivity for the removal of the HMs in the case of alkaline leachate.

Semicontinuous AD experiments revealed an early inhibition of the process, most probably linked to the presence of HSs in the MLL, whereas the accumulation of $\mathrm{NH}_{4}-\mathrm{N}$ up to a toxic level did not occur. Most probably, the inhibition was also exacerbated by the low HRT chosen, which favors wash-up of the active biomass, in addition to the relatively high dosage of MLL needed to reach the desired C/N values, because the tested co-substrate (cellulose) does not contain any nitrogen.

However, the value and the potential applications of the proposed treatment train (i.e., filtration using active materials and anaerobic co-digestion) remain intact. In fact, this process allows the use of the nitrogen present in the pre-treated MLL; moreover, several options exist for reducing or avoiding the inhibition due to HSs. The most promising of these are (i) a reduction in the pre-treated MLL dosage due to the fact that, for most substrates, it only results in limited nitrogen integration; (ii) an increase in the HRT to reduce the wash-off of the active biomass; and (iii) the addition of supplements of various type (salts or conductive materials) that may potentially reduce inhibition and/or enhance hydrolysis and methanization. Moreover, another interesting issue to explore would be to change the implementation of the AD process (e.g., batch or two phases).

For the possible pilot or full-scale implementation of this integrated process, it must be highlighted that the used synthetic MLL contains all the common leachate macroconstituents (e.g., organic matter including humic acids, ammonium, chlorides) and some of the micro-ones (e.g., HMs). Real MLLs can contain other micropollutants, normally present in limited concentration, so that the AD process would be most probably unaffected due to the limited amount of pretreated MLL to be added in the anaerobic reactor. However, with leachates of different composition, the duration of the filter material will be variable. In fact, its replacement will be guided by the desired characteristics of the pre-treated MLL. In addition, attention should be paid to the eventual presence of micropollutants strictly regulated by the norms for the agricultural use of the digestate derived from the process. As a consequence, further research in more realistic conditions (i.e., using a real MLL and a different $\mathrm{AD}$ substrate) is necessary to explore these options and to validate the results obtained herein.

Supplementary Materials: The following are available online at https:/ /www.mdpi.com/article/10 .3390 /w13202845/s1, Figure S1: experimental apparatus for leachate pre-treatment, Figure S2: Semicontinuous reactor, Table S1: Coefficient of uniformity, mean grain size, and particle density of materials, Table S2: Inoculum and substrate characterization, Table S3: $\mathrm{pH}$ values in MLL samples withdrawn from column tests, Table S4: TS content in weekly collected digestates, Table S5: VS content in weekly collected digestates.

Author Contributions: Conceptualization, P.S.C. and N.M.; methodology, P.S.C. and N.M.; investigation, F.F. and S.B.; writing—review and editing, P.S.C., N.M., F.F. and S.B.; visualization, F.F. and S.B.; supervision, P.S.C. and N.M. All authors have read and agreed to the published version of the manuscript.

Funding: This research received no external funding.

Data Availability Statement: The data presented in this study are available within the article and supplementary material. For the availability of detailed data sets the corresponding authors can be contacted.

Conflicts of Interest: The authors declare no conflict of interest. 


\section{References}

1. Gao, J.; Oloibiri, V.; Chys, M.; Audenaert, W.; Decostere, B.; He, Y.; Van Langenhove, H.; Demeestere, K.; Van Hulle, S.W.H. The present status of landfill leachate treatment and its development trend from a technological point of view. Rev. Environ. Sci. Biotechnol. 2014, 14, 93-122. [CrossRef]

2. Leary, P.R.O. Chapter 14 Landfilling. In Handbook of Solid Waste Management; Mcgraw-Hill: New York, NY, USA, $2002 ;$ pp. 1-94.

3. Renou, S.; Givaudan, J.G.; Poulain, S.; Dirassouyan, F.; Moulin, P. Landfill leachate treatment: Review and opportunity. J. Hazard. Mater. 2008, 150, 468-493. [CrossRef]

4. Christensen, T.H.; Kjeldsen, P. Basic Biochemical Processes in Landfills; Academic Press Ltd.: Cambridge, MA, USA, 1989.

5. Burton, S.A.Q.; Watson-Craik, I.A. Ammonia and nitrogen fluxes in landfill sites: Applicability to sustainable landfilling. Waste Manag. Res. 1998, 16, 41-53. [CrossRef]

6. Youcai, Z. Leachate Generation and Characteristics. Pollut. Control Technol. Leachate Munic. Solid Waste 2018, 1-30. [CrossRef]

7. European Union. Council Directive 1999/31/EC on the landfill. Off. J. Eur. Commu. 1999, L182/1-19. [CrossRef]

8. U.S. EPA. Solid Waste Disposal Facility Criteria; Final Rule. Federal Register, 40CFR Part 258, Part II Environmental Protection Agency, Volume 56, Number 196, 9 October, Rules and Regulations; US Department of Commerce: Washington, DC, USA, 1991.

9. Laner, D.; Crest, M.; Scharff, H.; Morris, J.W.F.; Barlaz, M.A. A review of approaches for the long-term management of municipal solid waste landfills. Waste Manag. 2012, 32, 498-512. [CrossRef] [PubMed]

10. Abbas, A.A.; Jingsong, G.; Ping, L.Z.; Ya, P.Y.; Al-Rekabi, W.S. Review on landfill leachate treatments. Am. J. Appl. Sci. 2009, 6, 672-684. [CrossRef]

11. Ehrig, H.J.; Robinson, H. Landfilling: Leachate Treatment; Christensen, T.H., Ed.; Solid Waste Technology and Management; John Wiley \& Sons Ltd.: Chichester, UK, 2010; Volume 2, pp. 858-897. ISBN 9781405175173.

12. Amor, C.; De Torres-Socías, E.; Peres, J.A.; Maldonado, M.I.; Oller, I.; Malato, S.; Lucas, M.S. Mature landfill leachate treatment by coagulation/flocculation combined with Fenton and solar photo-Fenton processes. J. Hazard. Mater. 2015, 286, 261-268. [CrossRef]

13. Torretta, V.; Ferronato, N.; Katsoyiannis, I.A.; Tolkou, A.K.; Airoldi, M. Novel and conventional technologies for landfill leachates treatment: A review. Sustainability 2017, 9, 9. [CrossRef]

14. Wu, C.; Chen, W.; Gu, Z.; Li, Q. A review of the characteristics of Fenton and ozonation systems in landfill leachate treatment. Sci. Total Environ. 2021, 762, 143131. [CrossRef] [PubMed]

15. Bilardi, S.; Calabrò, P.S.; Greco, R.; Moraci, N. Selective removal of heavy metals from landfill leachate by reactive granular filters. Sci. Total Environ. 2018, 644, 335-341. [CrossRef]

16. Bilardi, S.; Calabrò, P.S.; Greco, R.; Moraci, N. Removal of heavy metals from landfill leachate using zero valent iron and granular activated carbon. Environ. Technol. 2020, 41, 498-510. [CrossRef]

17. Bilardi, S.; Calabrò, P.S.; Moraci, N. The removal efficiency and long-term hydraulic behaviour of zero valent iron/lapillus mixtures for the simultaneous removal of $\mathrm{Cu}^{2+}, \mathrm{Ni}^{2+}$ and $\mathrm{Zn}^{2+}$. Sci. Total Environ. 2019, 675, 490-500. [CrossRef]

18. Bansal, R.C.; Goyal, M. Activated Carbon Adsorption; Taylor \& Francis: Boca Raton, FL, USA, 2005; ISBN 0-8247-5344-5.

19. Foo, K.Y.; Hameed, B.H. An overview of landfill leachate treatment via activated carbon adsorption process. J. Hazard. Mater. 2009, 171, 54-60. [CrossRef] [PubMed]

20. Angelidaki, I.; Alves, M.; Bolzonella, D.; Borzacconi, L.; Campos, J.L.; Guwy, A.J.; Kalyuzhnyi, S.; Jenicek, P.; Van Lier, J.B. Defining the biomethane potential (BMP) of solid organic wastes and energy crops: A proposed protocol for batch assays. Water Sci. Technol. 2009, 59, 927-934. [CrossRef]

21. Holliger, C.; Alves, M.; Andrade, D.; Angelidaki, I.; Astals, S.; Baier, U.; Bougrier, C.; Buffière, P.; Carballa, M.; De Wilde, V.; et al. Towards a standardization of biomethane potential tests. Water Sci. Technol. 2016, 74, 2515-2522. [CrossRef] [PubMed]

22. Alkalay, D.; Guerrero, L.; Lema, J.M.; Mendez, R.; Chamy, R. Review: Anaerobic treatment of municipal sanitary landfill leachates: The problem of refractory and toxic components. World J. Microbiol. Biotechnol. 1998, 14, 309-320. [CrossRef]

23. Oleszkiewicz, J.A.; Sharma, V.K. Stimulation and inhibition of anaerobic processes by heavy metals-A review. Biol. Wastes 1990, 31, 45-67. [CrossRef]

24. Liu, M.; Wei, Y.; Leng, X. Improving biogas production using additives in anaerobic digestion: A review. J. Clean. Prod. 2021, 297, 126666. [CrossRef]

25. Guo, Q.; Majeed, S.; Xu, R.; Zhang, K.; Kakade, A.; Khan, A. Heavy metals interact with the microbial community and affect biogas production in anaerobic digestion: A review. J. Environ. Manag. 2019, 240, 266-272. [CrossRef] [PubMed]

26. Fermoso, F.G.; Van Hullebusch, E.; Collins, G.; Roussel, J.; Mucha, A.P.; Esposito, G. Trace Elements in Anaerobic Biotechnologies; IWA Publishing: London, UK, 2019; ISBN 9781789060218.

27. Steinhauser, A.; Deublein, D. Biogas from Waste and Renewables Energy; John Wiley \& Sons: Hoboken, NJ, USA, $2011 ;$ ISBN 9783527327119.

28. Azman, S.; Khadem, A.F.; Zeeman, G.; van Lier, J.B.; Plugge, C.M. Mitigation of humic acid inhibition in anaerobic digestion of cellulose by addition of various salts. Bioengineering 2015, 2, 54-65. [CrossRef]

29. Li, J.; Hao, X.; van Loosdrecht, M.C.M.; Luo, Y.; Cao, D. Effect of humic acids on batch anaerobic digestion of excess sludge. Water Res. 2019, 155, 431-443. [CrossRef]

30. Calabrò, P.S.; Gori, M.; Lubello, C. European trends in greenhouse gases emissions from integrated solid waste management. Environ. Technol. 2015, 36, 2125-2137. [CrossRef] 
31. Riva, C.; Orzi, V.; Carozzi, M.; Acutis, M.; Boccasile, G.; Lonati, S.; Tambone, F.; D’Imporzano, G.; Adani, F. Short-term experiments in using digestate products as substitutes for mineral $(\mathrm{N})$ fertilizer: Agronomic performance, odours, and ammonia emission impacts. Sci. Total Environ. 2016, 547, 206-214. [CrossRef]

32. De Melo, B.A.G.; Motta, F.L.; Santana, M.H.A. Humic acids: Structural properties and multiple functionalities for novel technological developments. Mater. Sci. Eng. C 2016, 62, 967-974. [CrossRef] [PubMed]

33. Qasim, S.R.; Chiang, W. Sanitary landfill leachate: Generation, Control and Treatment; CRC Press: Boca Raton, FL, USA, 2017 ; ISBN 9781351417747.

34. Kjeldsen, P.; Barlaz, M.A.; Rooker, A.P.; Baun, A.; Ledin, A.; Christensen, T.H. Present and Long-Term Composition of MSW Landfill Leachate: A Review. Crit. Rev. Environ. Sci. Technol. 2002, 32, 297-336. [CrossRef]

35. Bilardi, S.; Calabró, P.S.; Moraci, N. Simultaneous removal of CU II, NI II and ZN II by a granular mixture of zero-valent iron and pumice in column systems. Desalin. Water Treat. 2015, 55, 767-776. [CrossRef]

36. Malara, A.; Paone, E.; Frontera, P.; Bonaccorsi, L.; Panzera, G.; Mauriello, F. Sustainable exploitation of coffee silverskin in water remediation. Sustainability 2018, 10, 3547. [CrossRef]

37. Chen, Y.; Cheng, J.J.; Creamer, K.S. Inhibition of anaerobic digestion process: A review. Bioresour. Technol. 2008, 99, 4044-4064. [CrossRef]

38. APHA; AWWA; WEF. Standard Methods for the Examination of Water and Wastewater, 22nd ed.; Rice, E.W., Baird, R.B., Eaton, A.D., Eds.; American Public Health Association; American Water Works Association; Water Environment Federation: Washington, DC, USA, 2012; ISBN 9780875530130.

39. Calabrò, P.S.; Fazzino, F.; Folino, A.; Scibetta, S.; Sidari, R. Improvement of semi-continuous anaerobic digestion of pre-treated orange peel waste by the combined use of zero valent iron and granular activated carbon. Biomass Bioenergy 2019, 129, 105337. [CrossRef]

40. Calabrò, P.S.; Fazzino, F.; Folino, A.; Paone, E.; Komilis, D. Semi-Continuous Anaerobic Digestion of Orange Peel Waste: Effect of Activated Carbon Addition and Alkaline Pretreatment on the Process. Sustainability 2019, 11, 3386. [CrossRef]

41. Ammary, B.Y. Nutrients requirements in biological industrial wastewater treatment. Afr. J. Biotechnol. 2004, 3, 236-238. [CrossRef]

42. Buchauer, K. A comparison of two simple titration procedures to determine volatile fatty acids in influents to waste-water and sludge treatment processes. Water SA 1998, 24, 49-56.

43. Liebetrau, J.; Pfeiffer, D.; Thrän, D. (Eds.) Collection of Measurement Methods for Biogas-Methods to Determine Parameters for Analysis Purposes and Parameters That Describe Processes in the Biogas Sector; Series of the Funding Programme "Biomass Energy Use"; Deutsches Biomasseforschungszentrum gemeinnützige GmbH: Leipzig, Germany, 2016; Volume 7, ISSN 2364-897X. Available online: https:/ / www.energetische-biomassenutzung.de/fileadmin/user_upload/Downloads/Ver\%C3\%B6_entlichungen/07 _MMS_Biogas_en_web.pdf (accessed on 22 September 2021).

44. Halim, A.A.; Aziz, H.A.; Johari, M.A.M.; Ariffin, K.S. Comparison study of ammonia and COD adsorption on zeolite, activated carbon and composite materials in landfill leachate treatment. Desalination 2010, 262, 31-35. [CrossRef]

45. Park, S.J.; Kim, B.J. Ammonia removal of activated carbon fibers produced by oxyfluorination. J. Colloid Interface Sci. 2005, 291, 597-599. [CrossRef] [PubMed]

46. Morawe, B.; Ramteke, D.S.; Vogelpohl, A. Activated carbon column performance studies of biologically treated landfill leachate. Chem. Eng. Process. Process Intensif. 1995, 34, 299-303. [CrossRef]

47. Zhou, D.; Li, Y.; Zhang, Y.; Zhang, C.; Li, X.; Chen, Z.; Huang, J.; Li, X.; Flores, G.; Kamon, M. Column test-based optimization of the permeable reactive barrier (PRB) technique for remediating groundwater contaminated by landfill leachates. J. Contam. Hydrol. 2014, 168, 1-16. [CrossRef]

48. Mohammad-Pajooh, E.; Turcios, A.E.; Cuff, G.; Weichgrebe, D.; Rosenwinkel, K.H.; Vedenyapina, M.D.; Sharifullina, L.R. Removal of inert COD and trace metals from stabilized landfill leachate by granular activated carbon (GAC) adsorption. J. Environ. Manag. 2018, 228, 189-196. [CrossRef]

49. Kurniawan, T.A.; Lo, W.H.; Chan, G.Y.S. Physico-chemical treatments for removal of recalcitrant contaminants from landfill leachate. J. Hazard. Mater. 2006, 129, 80-100. [CrossRef]

50. Wu, Y.; Guan, C.Y.; Griswold, N.; Hou, L.Y.; Fang, X.; Hu, A.; Hu, Z.Q.; Yu, C.P. Zero-valent iron-based technologies for removal of heavy metal(loid)s and organic pollutants from the aquatic environment: Recent advances and perspectives. J. Clean. Prod. 2020, 277, 123478. [CrossRef]

51. Madaffari, M.G.M.G.; Bilardi, S.; Calabrò, P.S.P.S.; Moraci, N. Nickel removal by zero valent iron/lapillus mixtures in column systems. Soils Found. 2017, 57, 745-759. [CrossRef]

52. Wasay, S.A.; Barrington, S.; Tokunaga, S. Efficiency of GAC for treatment of leachate from soil washing process. Water. Air. Soil Pollut. 1999, 116, 449-460. [CrossRef]

53. Reed, B.E. Identification of Removal Mechanisms for Lead in Granular Activated Carbon (GAC) Columns. Sep. Sci. Technol. 1995, 30, 101-116. [CrossRef]

54. Chen, J.P.; Wang, X. Removing copper, zinc, and lead ion by granular activated carbon in pretreated fixed-bed columns. Sep. Purif. Technol. 2000, 19, 157-167. [CrossRef]

55. Modin, H.; Persson, K.M.; Andersson, A.; van Praagh, M. Removal of metals from landfill leachate by sorption to activated carbon, bone meal and iron fines. J. Hazard. Mater. 2011, 189, 749-754. [CrossRef] [PubMed]

56. Bilardi, S.; Calabrò, P.S.; Moraci, N.; Madaffari, M.G.; Ranjbar, E. A comparison between Fe 0/pumice and Fe 0/lapillus mixtures in permeable reactive barriers. Environ. Geotech. 2020, 7, 524-539. [CrossRef]

57. Viana, M.B.; Freitas, A.V.; Leitão, R.C.; Pinto, G.A.S.; Santaella, S.T. Anaerobic digestion of crude glycerol: A review. Environ. Technol. Rev. 2012, 1, 81-92. [CrossRef]

58. Yenigün, O.; Demirel, B. Ammonia inhibition in anaerobic digestion: A review. Process Biochem. 2013, 48, 901-911. [CrossRef] 